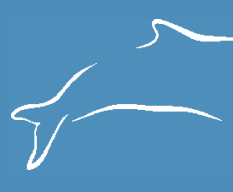

\title{
Foraging trips of female South American sea lions (Otaria flavescens) from Isla Chañaral, Chile
}

\section{Article Info}

\begin{tabular}{|c|c|}
\hline Manuscript type & Note \\
\hline \multicolumn{2}{|l|}{ Article history } \\
\hline Received & 03 January 2011 \\
\hline Received in revised form & 04 April 2011 \\
\hline Accepted & 20 April 2011 \\
\hline Available online & 27 January 2014 \\
\hline \multicolumn{2}{|c|}{ Responsible Editor: Carlos E. Olavarría } \\
\hline \multicolumn{2}{|c|}{$\begin{array}{l}\text { Citation: Muñoz, L., Pavez, G., Inostroza, P. and Sepúlveda, } \\
\text { M. (2011) Foraging trips of female South American sea lions } \\
\text { (Otaria flavescens) from Isla Chañaral, Chile. Latin American } \\
\text { Journal of Aquatic Mammals } 9(2): 140-144 \text {. }\end{array}$} \\
\hline \multicolumn{2}{|c|}{ http://dx.doi.org/10.5597/lajam00178 } \\
\hline
\end{tabular}

Depending on whether they are capital or income breeders, pinnipeds have different strategies of nursing and maternal care (Atkinson, 1997; Riedman, 1990; Boyd, 2000). In capital breeders such as most phocids, lactation is of short duration (4-50d), after which pups are weaned (Oftedal et al., 1987; Boness and Bowen, 1996; Hammill, 2002). By contrast, otariids are income breeders with a relatively long cycle of maternal care ( $4 \mathrm{mo}$ to $3 \mathrm{yr}$ ). Thus lactating otariid females must divide their time between offspring on land and foraging trips in the ocean (Bonner, 1984; Oftedal et al., 1987; Campagna and Le Boeuf, 1988). The time spent on land with the pup ranges from 0.5 to $4 \mathrm{~d}$ (Oftedal et al., 1987) following the initial perinatal attendance period. This time is variable among species (e.g., Harcourt et al., 1995; Francis et al., 1998; Arnould and Hindell, 2001; Rehberg et al., 2009) and depends on the age of the pup (Riedman, 1990). There is also considerable variation in the duration of foraging trips, which ranges from 0.6d in the Steller's sea lion (Eumetopias jubatus) (Rehberg et al., 2009) to 23d in the Juan Fernández fur seal (Arctocephalus philippii) (Francis et al., 1998). This variability in both duration of foraging trips and attendance periods could be affected by intrinsic factors, such as the age of the pup (Oftedal et al., 1987) and external factors such as the productivity of the area (Francis et al., 1998, Bailleul et al., 2005) which may vary seasonally (Harcourt et al., 2002) or with unpredictable environmental oscillations such as El Niño (Oftedal et al., 1987; Soto et al., 2006).

The productivity of the area is one of the determining factors in the duration of foraging trips in lactating females (McCafferty et al., 1998). Variation in availability and abundance of prey may generate changes in foraging behavior

\author{
Lily Muñoz ${ }^{\dagger}$, Guido Pavez ${ }^{\dagger}$, Patricia Inostroza \\ Maritza Sepúlveda \\ ${ }^{\dagger}$ Facultad de Ciencias del Mar y de Recursos Naturales, Universidad de \\ Valparaíso. \\ ‡Centro de Investigación y Gestión de los Recursos Naturales (CIGREN), \\ Facultad de Ciencias, Universidad de Valparaíso, Chile. Av. Gran Bretaña \\ 1111, Playa Ancha, Valparaíso, Chile. \\ *Corresponding author, e-mail: maritza.sepulveda@uv.cl
}

(Boyd et al., 1994; Harcourt et al., 2002). For example, studies on the Antarctic fur seal (A. gazella) have compared foraging behavior between years with high and low productivity in the same site (Mc Cafferty et al., 1998), as well as between areas of high and low productivity in the same year (Staniland et al., 2010), demonstrating that females make shorter foraging trips and shorter dives in years and areas with high productivity. Thus, it is expected that duration of foraging trips of lactating females will vary inversely with the productivity of the area (Francis et al., 1998).

The South American sea lion (Otaria flavescens) has one of the widest distributions of all sea lions. In South America it is found both on the Pacific (Perú and Chile) and the Atlantic (South Brazil, Uruguay and Argentina) coasts (Vaz-Ferreira, 1982). The Atlantic and Pacific coasts have considerable differences in productivity, which are reflected in commercial fisheries harvests. For example, between 1960 and 2002 captures in the southeastern Pacific (Perú and Chile) averaged 8 million t annually, while in the southwestern Atlantic (Brazil, Uruguay and Argentina) in the same period, the average annual harvest was only 500,000t (FAO, 2003). This large difference in productivity between oceans is due principally to the influence of the Humboldt Current near the coast in the Pacific Ocean, which maintains one of the most productive fishing zones of the world (Neira and Arancibia, 2004) and thus provides abundant food for the South American sea lion population.

Considering published information for other species of otariids (Francis et al., 1998; Mc Cafferty et al., 1998; Arnould and Hindell, 2001; Rehberg et al., 2009; Staniland et al., 2010) and the greater biological productivity of the Pacific 


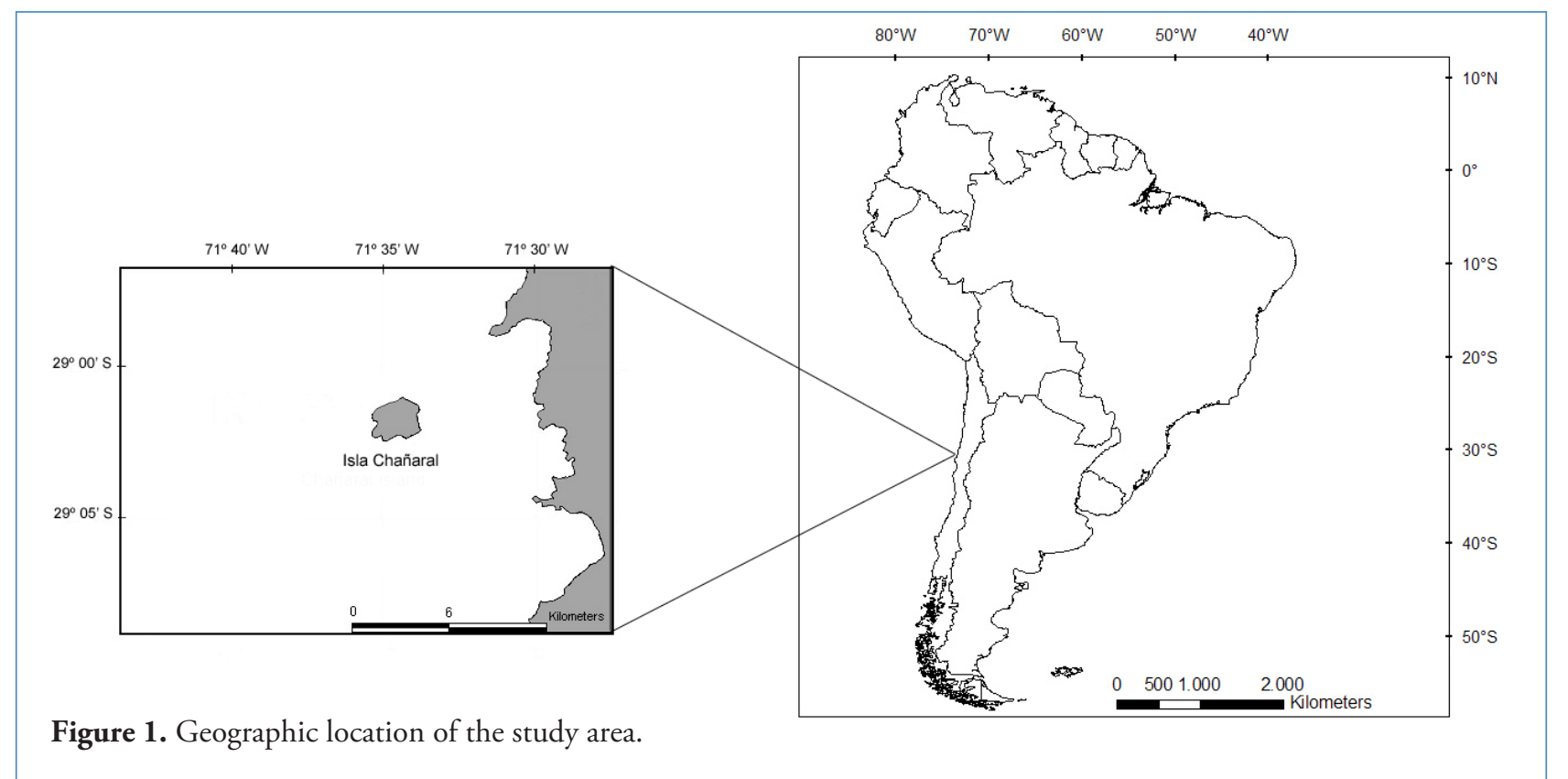

coast, we should expect that duration of foraging trips of lactating females in Chile should be of shorter duration than those lactating females of the Atlantic coast (Sherman, 1994). However, there is only information on duration of foraging trips in the Atlantic coast; where trips averaged $0.9 \mathrm{~d}$ (range: 0.6-1.2d) in the Falkland/Malvinas Islands (Thompson et al., 1998), and 3.4d (range: 2.6-3.9d) in the continental shelf of Argentinean Patagonia (Campagna et al., 2001). The aim of the present study was to characterize, for the first time in Chile, the duration of foraging trips of lactating female South American sea lions off the north-central Chilean region, and to compare them with those from the Atlantic coast.

This study was performed in the reproductive colony of South American sea lions located at Isla Chañaral (2902'S, $\left.71^{\circ} 36^{\prime} \mathrm{W}\right)$, which is part of the Reserva Marina Isla Chañaral and the Reserva Nacional Pingüino de Humboldt, in northcentral Chile (Figure 1). The colony was divided into four sectors; sectors $\mathrm{A}$ and $\mathrm{B}$, comprising mostly adult males and solitary sub-adult males, and sectors $\mathrm{C}$ and D, where reproductive harems were found. We selected Sector D as the study area because of easier access and visibility for observations.

We marked a total of five lactating females and 15 newborn pups using a modification of a previously used methodology (Kirkwood et al., 2005; Soto et al., 2006). A $5 \mathrm{ml}$ mixture of bleaching powder and hydrogen peroxide (commercially know as Blondor (Wella), a product for human hair) was placed in previously emptied chicken eggs, and dropped on the animals from about $10 \mathrm{~m}$ above them. We also identified one female and two pups by natural marks (scars and injuries). Using both natural and artificial markings, we constructed an identification catalog and assigned a number to each individual. Figure 2 shows an example of a marked female and pup. We were able to successfully follow the movements of six lactating females and six pups, including three motherpup pairs.

From 2 to 18 February 2010 we recorded the presencel absence of the marked females in the colony. Every day

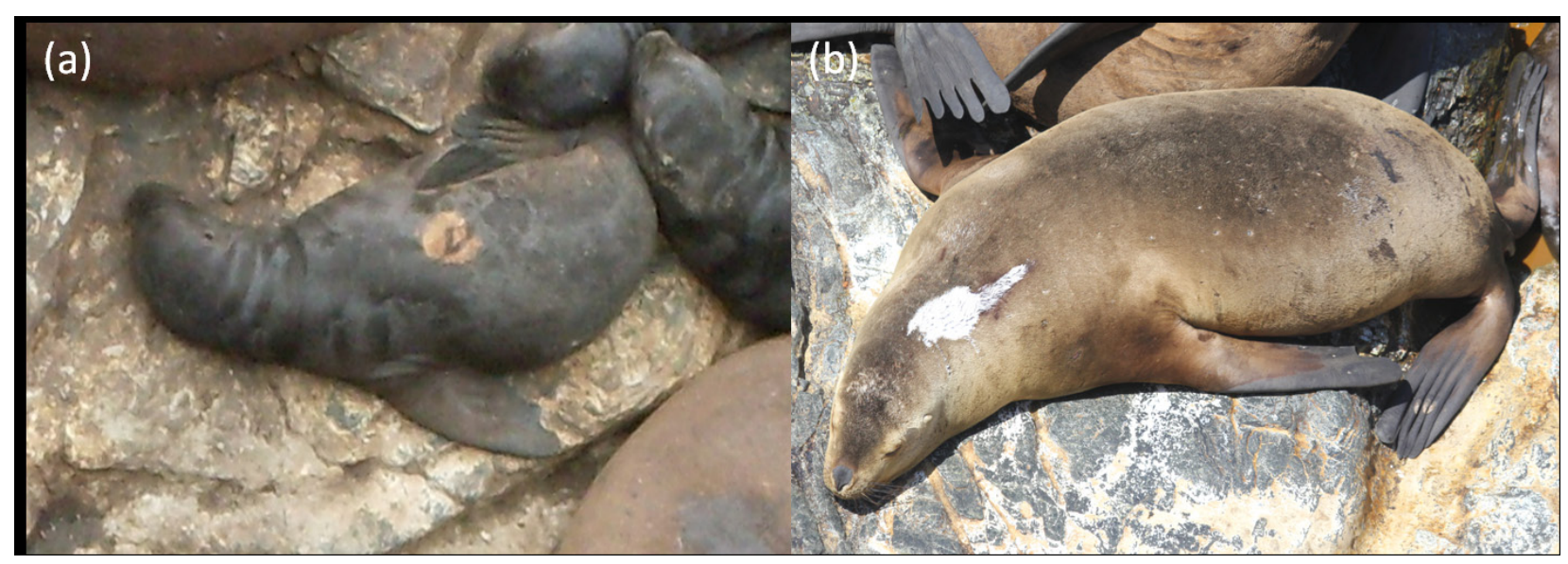

Figure 2. (a) Pup with bleach mark on the side, and (b)

lactating female with bleach mark on the head. 
observations were made by three investigators in two intervals of two hours, from 10:00 to $12: 00 \mathrm{~h}$ and from 15:00 to 17:00h. Identification and behavioral observations were made using Leupold 7x50 binoculars.

We considered a foraging trip to be the time period from the first to last interval in which a marked lactating female was not observed. Presence in the colony was measured as the time period from the first interval a female was observed in the colony until the last interval her presence was recorded. This time period was approximated and expressed in days (i.e. one and two consecutive intervals are considered as one day, three and four intervals are considered as two days and so on). If pups were observed without their mothers we assumed the mothers were feeding in the ocean.

We compared trip time and presence time by means of the non-parametric Spearman correlation analysis, since the data did not satisfy the requirements of normality and homoscedasticity (Zar, 1996). The analysis was performed using the statistical software Statistica 7.0 (StatSoft Inc., 2004).

During the study period, we recorded a total of 48 foraging trips, with a mean $( \pm S D)$ of $8 \pm 1.4$ trips per female. The duration of these trips was from 1 to $4 \mathrm{~d}$; the most frequent duration was $1 \mathrm{~d}$, representing $52 \%$ of the trips (Figure $3 \mathrm{a}$ ). These trips alternated with periods in which the females stayed on land with their pups (attendance period); with a duration of 1 to $4 \mathrm{~d}$, most frequently (55\%) 1d (Figure 3b). We did not find a significant correlation between the foraging trips duration and the attendance period on land $(r=-0.066$; $p>0.05$ ).

Although our results are still preliminary, with a low number of marked females and only at the beginning of lactation, this is the first study of the duration of foraging trips and attendance period on land of lactating females of O. flavescens in the Chilean coast. Boness and Bowen (1996), based on existing studies of feeding in different species of pinnipeds, suggested that duration of foraging trip varies between sea lions and fur seals. Foraging trips of fur seals species have been described as lasting from 3 to $23 \mathrm{~d}$, albeit individual trips as short as $3.4 \mathrm{~h}$ have been recorded (Arnould and Boyd, 1996; Francis et al., 1998; Harcourt et al., 1995; 2002; McCafferty et al., 1998; Arnould and Hindell, 2001). In contrast, the duration of foraging trip of sea lions usually last 1 to $4 \mathrm{~d}$ (Campagna and Le Boeuf, 1988; Thompson et al., 1998; Campagna et al., 2001; Rehberg et al., 2009), which is similar to that recorded in this study.

The duration of foraging trips we recorded is also consistent with the results of Thompson et al. (1998) for the same species in the Falkland Islands, but is considerably shorter than found by Campagna et al. (2001) in Argentinean Patagonia. The differences in duration of foraging trips found in these two studies from the Atlantic are reflected in the different distances that the females traveled from the haul-out to their foraging area. The females marked by Thompson et al. (1998) travelled a mean distance of about $46 \mathrm{~km}$, with a

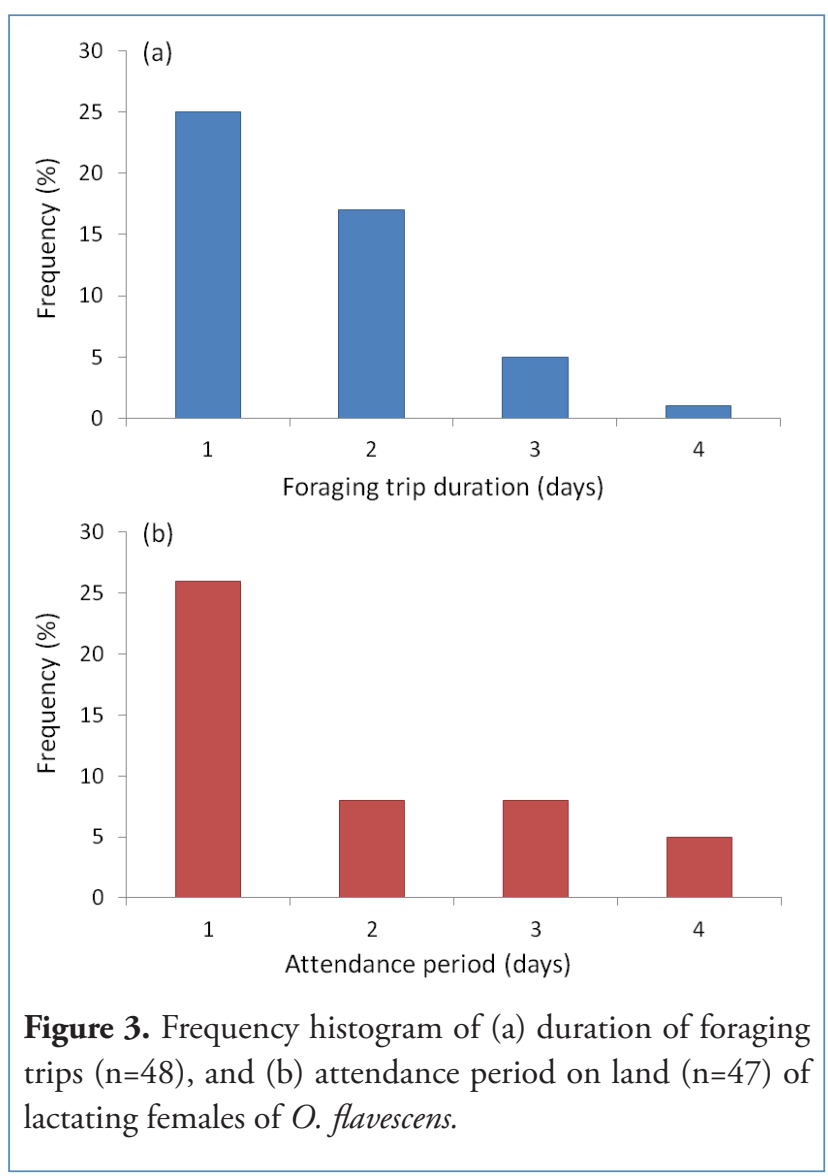

maximum of $125 \mathrm{~km}$. By contrast, Campagna et al. (2001) recorded a mean distance of $206 \mathrm{~km}$ with a maximum of $524 \mathrm{~km}$, reaching distances of 19 to $258 \mathrm{~km}$ from the colony. Although in our study we did not record the distance traveled by the females, the results from the Atlantic suggest that the lactating females of the Isla Chañaral do not have to go very far from the rookery to feed.

The similarity between our results and the study by Thompson et al. (1998) may be due to the fact that the Falkland/Malvinas Islands area, as well as Isla Chañaral, corresponds to an area of high productivity. The study area is part of the Humboldt Current system and is located near a highly dynamic costal upwelling zone that results in one of the most productive fishing industries in the world (Montecino et al., 1996; Montecino and Quiroz, 2000). This region is also a nutritional source for a diverse group of marine birds and mammals (Pérez et al., 2006; Sepúlveda et al., 2007). The Falkland/Malvinas Islands are very close to the shelf-break front, with highly productive waters. That area is one of the most important fishing grounds of the South Atlantic, being an important feeding area for many marine mammals and seabirds (Foro para la Conservación del Mar Patagónico y áreas de influencia, 2008). This great productivity may allow females of $O$. flavescens to feed in areas near the colonies, thus decreasing the time they spend away from their offspring (Thompson et al., 1998). As mentioned above, the relationship between the productivity and duration 
of foraging trips has been found in other species of otariids, in which lactating females in the presence of abundant food make shorter foraging trips, with shorter dives and longer periods on land (McCafferty et al., 1998). However, as our study occurred only during early lactation we cannot rule out the demands of young pups constraining foraging trip time for their mothers.

The lack of a relationship between duration of foraging trip and attendance period on land with the pups was also reported for this species (Campagna et al., 2001) and for other species of otariids (Bailleul et al., 2005). However, due to the small sample size, our results should be taken with caution. Other factors may generate variation in both variables, such as the productivity level of the feeding areas (Bailleul et al., 2005) and the age of the pup (Arnould and Hindell, 2001; Harcourt et al., 2002), which should be evaluated in future studies.

For future studies in this area, it is necessary to consider a greater sample size and longer observation periods, in order to obtain a more complete understanding of the duration of foraging trips. The use of satellite marking may also allow us to identify the foraging areas of this species off north-central Chile, to determine the distance covered in each trip, to determine the time foraging trip ends and the arrival time at the rookery, and thus to provide a more complete description of the foraging process and the duration of the foraging trips. These studies should be accompanied by monitoring of abundance and availability of prey species, since this may have a direct relation to the behavior of lactating females during foraging trips.

\section{Acknowledgements}

We thank Daniela Catalán, Franco Bueno and Priscila Paredes for their help with data collection in the field, Jeanette Santana for their bibliographic support, Patricio Ortiz for logistic support in the field and Lafayette Eaton for editing the text. A special thanks to the Corporación Nacional Forestal (CONAF-Atacama) for authorizing the work in the Isla Chañaral, especially to Carla Louit, Pablo Arrospide and José Núnez for logistic support while we were on the island. Our study was conducted under the scientific permit ORD. $\mathrm{N}^{\circ}$ 2/2010 issued by CONAF. Thanks to John Arnould, Rob Harcourt and two anonymous reviewers, and the Associate Editor Carlos Olavarría for helpful comments on this manuscript.

\section{References}

Arnould, J.P.Y and Boyd, I. L. (1996) The relationship between foraging behaviour and energy expenditure in Antarctic fur seals. Journal of Zoology 239: 769-782. http://dx.doi.org/10.1111/j.1469-7998.1996.tb05477.x .

Arnould, J.P. and Hindell, M.A. (2001) Dive behavior, foraging locations, and maternal-attendance patterns of Australian fur seals (Arctocephalus pusillus doriferus). Canadian Journal of Zoology 79: 35-48. http://dx.doi.org/10.1139/cjz-79-1-35
Atkinson, S. (1997) Reproductive biology of seals. Reviews of Reproduction 2: 175-194. http://dx.doi.org/10.1530/ror.0.0020175.

Bailleul, F., Luque, S., Dubroa, L., Arnould, J.P.Y. and Guinet, C. (2005) Differences in foraging strategy and maternal behavior between two sympatric fur seal species at the Crozet Islands. Marine Ecology Progress Series 293: 273282. http://dx.doi.org/10.3354/meps293273

Boness, D.J. and Bowen, W.D. (1996) The evolution of maternal care in pinnipeds. Bioscience 46: 645-654. http://dx.doi.org/10.2307/1312894

Bonner, W.N. (1984) Lactation strategies in pinnipeds: problems for a marine mammal group. Symposium Zoological Society London 51: 253-272.

Boyd,I.L.(2000)State-dependentfertilityin pinnipeds: contrasting capital and income breeders. Functional Ecology 14: 623-630, http://dx.doi.org/10.1046/j.1365-2435.2000.t01-1-00463.x

Boyd, I.L., Arnould, J.P., Barton, T. and Croxall, J.P. (1994) Foraging behavior of Antarctic fur seals during periods of contrasting prey abundance. Journal of Animal Ecology 63: 703-713. http://dx.doi.org/10.2307/5235.

Campagna, C. and Le Boeuf, B. J. (1988) Reproductive behavior of southern sea lions. Behavior 104: 233-261. http://dx.doi.org/10.1163/156853988X00539.

Campagna, C., Werner, R., Karesh, W., Marín, M., Koontz, F., Cook, R. and Koontz, C. (2001) Movements and location at sea of South American sea lions (Otaria flavescens). Journal of Zoology 257: 205-220. http://dx.doi.org/10.1017/S0952836901001285

FAO Yearbook (2003). Yearbook of Fisheries Statistics Vol. 93. Rome, Italy.

Foro para la Conservación del Mar Patagónico y Áreas de Influencia (2008) Sintesis del estado de conservación del Mar Patagónico y áreas de influencia. Edición del Foro, Puerto Madryn, Argentina.

Francis, J., Boness, D. and Ochoa-Acuña, H. (1998) A protracted foraging and attendance cycle in female Juan Fernández fur seals. Marine Mammal Science 14: 552-574. http://dx.doi.org/10.1111/j.1748-7692.1998.tb00742.x

Hammill, M.O. (2002) Earless seals. Pages 352-358 in Perrin, W.F., Würsig, B. and Thewissen, J.G.M. (Eds) Encyclopedia of Marine Mammals. Academic Press, San Diego, USA.

Harcourt, R.G., Schulman, A., Davis, L.S. and Trillmich F. (1995) Summer foraging by lactating female New Zealand fur seals (Arctocephalus forsteri) off Otago Peninsula, New Zealand. Canadian Journal of Zoology 73: 678-690. http://dx.doi.org/10.1139/z95-080

Harcourt, R.G., Bradshaw, C.J., Dickson, K. and Davis, L.S. (2002) Foraging ecology of a generalist predator, the female New Zealand fur seal. Marine Ecology Progress Series 227: 11-24. http://dx.doi.org/10.3354/meps227011 
Kirkwood, R., Gales, R., Terauds, A., Arnould, J.P.Y., Pemberton, D., Shaughnessy, P.D., Mitchell. A.T. and Gibbens J. (2005) Pup production and population trends of the Australian fur seal (Arctocephalus pusillus doriferus). Marine Mammal Science 21:260-282

http://dx.doi.org//10.1111/j.1748-7692.2005.tb01227.x

McCafferty, D., Boyd, I.L., Walker, T.R. and Taylor, R.Y. (1998) Foraging responses of Antarctic fur seals to changes in the marine environment. Marine Ecology Progress Series 166: 285-299. http://dx.doi.org/10.3354/meps 166285

Montecino, V., Pizarro, C. and Quiroz, D. (1996) Dinámica fitoplanctónica en el sistema de surgencia frente a Coquimbo $\left(30^{\circ} \mathrm{S}\right)$ a través de la relación funcional entre fotosíntesis e irradianza (P-I). Gayana Oceanologia 4: 139-151.

Montecino, V. and Quiroz, D. (2000) Specific primary production and phytoplankton cell size structure in an upwelling area off the coast of Chile $\left(30^{\circ} \mathrm{S}\right)$. Aquatic Sciences 62: 364-380. http://dx.doi.org/10.1007/PL00001341.

Neira, S. and Arancibia, H. (2004) Trophic interactions and community structure in the Central Chile marine ecosystem $\left(33^{\circ} \mathrm{S}-39^{\circ} \mathrm{S}\right)$. Journal of Experimental Marine Biology and Ecology 312: 349-366. http://dx.doi.org/10.1016/j.jembe.2004.07.011.

Oftedal, O., Boness, D. and Tedman, R. (1987) The behavior, physiology and anatomy of lactation in the Pinnipedia. Pages 175-245 in Genoways, H.H. (Ed) Current Mammalogy. Plenum Publishing Corporation, New York, USA.

Pérez, M.J., Thomas, F., Uribe, F., Sepúlveda, M., Flores, M. and Moraga, R. (2006) Fin whales (Balaenoptera physalus) feeding on Euphasia mucronata in nearshore waters off North- Central Chile. Aquatic mammals 32: 109-113. http://dx.doi.org/10.1578/AM.32.1.2006.109

Rehberg, M.J., Andrews, R.D., Swain, U.G. and Calkins, D.G. (2009) Foraging behavior of adult female Steller sea lions during the breeding season in Southeast Alaska. Marine Mammal Science 25: 588-604. http://dx.doi.org/10.1111/j.1748-7692.2008.00278.x
Riedman, M. (1990) The pinnipeds: seals, sea lions and walruses. University of California Press, Berkeley, California, USA.

Sepúlveda, M., Pérez, M.J., López, P. and Moraga, R. (2007) Presence and re-sighting of southern elephant seal, Mirounga leonina (L. 1758), on the central coast of Chile. Latin American Journal of Aquatic Mammals 6: 199-202. http://dx.doi.org/10.5597/lajam00126

Sherman, K. (1994) Sustainability, biomass yields, and health of coastal ecosystems: an ecological perspective. Marine Ecology Progress Series 112: 277-301. http://dx.doi.org/10.3354/meps 112277

Soto, K.H., Trites, A.W. and Arias-Schreiber, M. (2006) Change in diet and maternal attendance of South American sea lions indicate changes in the marine environment and prey abundance. Marine Ecology Progress Series 312: 277-290,. http://dx.doi.org/10.3354/meps312277

Staniland, I.J., Gales, N., Warren, N.L., Robinson, S.L., Goldsworthy, S.D. and Casper, R.M. (2010) Geographical variation in the behavior of a central place forager: Antarctic fur seals foraging in contrasting environments. Marine Biology 11: 2383-2396. http://dx.doi.org/10.1007/s00227-010-1503-8

Thompson, D., Duck, C.D., Mc Conell, B.J. and Garret, J. (1998) Foraging behavior and diet of lactating female southern sea lions (Otaria flavescens) in the Falkland Islands. Journal of Zoology 246: 135-146. http://dx.doi.org/10.1111/j.1469-7998.1998.tb00142. x

Vaz-Ferreira, R. (1982) Otaria flavescens (SHAW), South American sea lion. Pages 447-495 in Mammals in the seas: small cetaceans, seals, sirenians and otters. FAO Fisheries Series 5, Rome, Italy.

Zar, J.H. (1996) Biostatical analysis. $3^{\text {rd }}$ ed. Prentice-Hall, New Yersey, USA. 